\title{
Screening and Evaluation of Exotic and Indigenous Walnut Genotype and Varieties
}

\author{
Nasar Ali Khan ${ }^{1 *}$, Nadia Bostan¹, Nawab Ali², Muhammad Mehran Anjum², Asif Iqbal ${ }^{1}$, Fayaz Khan¹, Imatiaz \\ Khan $^{3}$, Bacha Room ${ }^{1}$ and Abdul Latif ${ }^{3}$ \\ ${ }^{1}$ Department of Horticulture, The University of Agriculture Peshwar, Pakistan \\ ${ }^{2}$ Department of Agronomy, The University of Agriculture Peshwar, Pakistan
}

${ }^{3}$ Department of Plant Protection, The University of Agriculture Peshwar, Pakistan

Submission: March 01, 2017; Published: May 30, 2017

"Corresponding author: Nasar Ali Khan, Department of Horticulture, The University of Agriculture Peshwar-Pakistan, Email: nasaralikhan5151@gmail.com

\begin{abstract}
A trail to investigate the "screening and evaluation of exotic and indigenous walnut genotype and varieties" was conduct at Agriculture Research Institute (ARI) Swat during 2015. Thirteen genotypes such as G-04, G-09, G-10, G-12, G-13, G-15, G-16, G-17, G-19, G-20, G-26, G-29, G-33 and varieties such as Paynee and Serr. The parameters studied were picking dates, nuts with husk weight, nuts fresh weight, dried nuts weight, kernel percentage, nuts size, kernel color, kernel test, fruit color, yield per plant, number of nuts per kg. Regarding genotypes (G-10, G-13, G-26 and G-33) were observed as early picking, (G-17, G-20, G-29) as mid picking and (G-04, G-09, G-12, G-15, G-16, G19) as late picking. (G-15, G-16) showed light, (G-17) Amber, while (G-04, G-09, G-12, G-13, G-19, G-20, G-26, G-29, G-33) showed light Amber, and (G-10) was dark Amber in color. Very good, good and fair, kernel taste was noted in (G-19, G-20), (G-10, G-12, G-13, G-15, G-16, G-26, G-29, G33) and (G-04, G-09, G-17) respectively. Maximum nut with husk weight $(80.0 \mathrm{~g})$ fresh weight $(29 \mathrm{~g})$ and dried weight $(21.1 \mathrm{~g})$ was recorded in $\mathrm{G}-15$.

On the other hand maximum kernel percentage (55\%), number of nuts [1-3] per kg were recorded for G-13, and nuts size (1840.4mm²) for G-12, while yield $(15.200 \mathrm{~kg})$ per plant was noted for G-10, whereas the minimum nut size $\left(937.9 \mathrm{~mm}^{2}\right)$, nut fresh weight $(11.5 \mathrm{~g})$ and nut dried weight (8.1g) was noted in G-13. Minimum number of nuts (50) per kg was recorded in G-15, minimum nut with husk weight was noted in G-4 $(29.0 \mathrm{~g})$ and minimum yield $(10.250 \mathrm{~kg})$ was recorded in G-12, while minimum kernel percentage (38\%) was noted in G-15. In case of varieties Paynee and Serr were noted as late picking varieties having good kernel test with light and extra light kernel color. Maximum nut with husk weight $(22.9 \mathrm{~g})$ fresh weight $(17.3 \mathrm{~g})$ dried weight (12.8g) kernel percentage $(50 \%)$ nut size $\left(1356.6 \mathrm{~mm}^{2}\right)$ was observed in Serr. On the other hand Paynee showed maximum kernel percentage (54\%), yield $(15 \mathrm{~kg})$ per tree and number of nuts (105) per kg, whereas minimum number of nuts (101) per $\mathrm{kg}$ was observed in Serr.
\end{abstract}

Keywords: Germplasam; Walnut; Varieties; Genotypes

\section{Introduction}

Walnut belongs to the family Juglandaceae and genus Juglans. The family consists of about 60 species, 21 of which are placed in the genus Juglans. However, the most important among them are Juglans regia L and Juglans nigra L. [4] that are famous for their delicious kernel and valuable wood. Persian walnut (Juglans regia $L$ ) is an ancient species [5] originated in Central Asia, the West Himalayan chain and 4 Kyrgystan [6]. Walnuts are the most widely distributed of all nut species and have been appreciated by human beings since ancient times. It has been cultivated in southern Europe since 1000 BC [7]. Walnuts are growing in the Northern Pakistan since time immemorial and are one of the most important nut crops grown in Malakand division. Malakand division contributes about $82 \%$ of the total walnut production of the country [8]. The walnut trees in Malakand division are mostly of seedling origin and exhibit considerable variability in nuts size, shape, shell thickness and color, quality and color of kernel and in other morphological attributes. There are no regular orchards of walnut in the area; however, significant numbers of trees are grown on marginal lands in diffused plantations and thus are a source of additional income of the farming community.

In Malakand division, due to the extensive local use of walnut bark and timber, the specie is being aggressively harvested. Swat valley is the best place for walnut production and account around 35 percent of the country's walnut population. In Swat walnut occupies 500 ha out of the total 1,497ha. Mostly, Swat walnut is exported due to its high quality and demand. Kernels of good 
quality have good price and there is especially a high demand for thin-shelled walnut (Kaghzi akhrot) in market [9]. Walnut has a number of medicinal and non-food uses. Traditionally, since time immemorial, walnut bark has been used for teeth cleaning and curing gum diseases. Walnut consists of mostly omega-3 and omega- 6 polyunsaturated fattyacids, which are essential dietary fatty acids and helps in the prevention of coronary heart diseases [10]. Nut consumption is associated with a protective effect against coronary heart disease, partly due to its high antioxidant content [11].

Walnut husk yields valuable oil and yellowish dye when pressed. The oil is used in soaps, paints, and making dye. Walnut has high nutritional value. It is rich in proteins (14-24\%), fats (52-70\%) and vitamins; especially vitamins B group and E, while in minerals; $\mathrm{K}$ and $\mathrm{Mg}$ are worth mentioning. Important amino acids are glutamic acid, arginine and leucine. Taurine (2-amino ethyl sulfonic acid), an organic acid and a derivative of the sulfur-containing amino acid cystine is found in variable quantities between 0.2 and $0.6 \mathrm{mg} \%$ ). It is an important compound and involved in many functions; homeostatic regulation, thermoregulation, nervous conduction, protection against oxidative stress [12]. Walnut tree is medium to large with spreading crown. The leaf is compound consisting of 7-11 leaflets. Walnut tree is perennial, monoecious and mostly cross-pollinated. It shows high variability in both pomological and phenological traits. Male (catkins) and female (pistillate) flowers are borne on the same tree. Catkins are borne laterally on one-year old shoots while pistillate flowers borne terminally or laterally on current season's growth in spikes of typically 2-3 flowers (some times more than three).

It is heterogamous, either protoandrous (male flowers mature first) or protogynous (female flowers mature first) depending upon the cultivars. This dichogamy encourages cross pollination and thus production mainly depends on wind pollination and bloom overlap [13]. Nuts are borne singly or in clusters and a green, fleshy husk surrounds it, which splits irregularly at maturity. Walnut is extremely sensitive to site conditions and should only be planted on the most suitable frost free, fertile, well drained and deeply root able sites [14]. The wood of walnut is regarded to be as one of the most valuable woods in the world for high grade furniture [15]. Common methods of propagation are tongue, cleft and hypocotyle grafting. However, chip and patch budding can also be used as propagation methods.

There are up to 50 different genotypes of Juglatis regia cultivated in different areas of Pakistan that is in the KPK province including Malakand division (districts of Swat, Dir, Bunir, Chitral, Shangla and Malakand Agency), Kaghan (district Mansehra), in Gilgit-Baltistan province have a number of walnut clusters, and Leepa in Neelum valley and Muffazarabad in Azad Jammu \& Kashmir Ali et al. [9] while Murree Hills in Punjab have sparse plantations. Approximately, 35,000 families cultivate walnut for their livelihood. This production is consumed locally and also exported to some countries. Individual walnut trees are grown along boundaries of fields, channels, and backyards, etc. Mostly Pakistan seedlings are commercially grown, however some exotic cultivars have also been tried from time to time at research stations such as 'Chandler', 'Hartley', 'Lam', 'Germisara', lupanesti', 'Valerie,'Odum', 'Sere and 'Sulemani' [16] and many local selections like `MS-1', 'MS-2', 'MS-18' from Malakand, 'SW$1^{\prime}$, 'SW-3' from Swat, 'Dir-2' and 'Chitral-I', 'Chitral-2', 'Chitral-3', (, 'Kurram-1','Kurram-2', 'Kurram-3', 'Kurram-4' [17].

Good research work has been going on with characterization of 226 genotypes collected from various locations of Malakand [18]. Genotypes present in Dir, Chitral, Swat and Leepa (Neelum, AJ \& K) are superior in various qualitative and quantitative traits to the adopted exotic varieties i.e., 'Serr' and 'Paynee'. Pakistan has a tremendous population of indigenous walnut germplasm, but multiplication by seeds give variation in the orchards. Therefore nursery men need to use vegetative means of propagation to provide true types plants with better production capability. Keeping in view the best agro climatic conditions of Swat for walnut production this study was designed to screen and evaluate indigenous walnut varieties in Agriculture Research Institute Mingora Swat to determine the fruit size, quality and yield of walnut [19-30].

\section{Materials and Methods}

The study of Screening and evaluation of exotic and indigenous walnut germ plasm was conducted at Agriculture Research Institute Mingora Swat during 2015. The focal objective was to identify high yielding genotypes in Agriculture Research Institute Mingora Swat for better fruit size, fruit quality and yield of walnut.

\section{Experimental design}

There were thirteen different genotypes and two varieties of walnut and each having two trees, thus sixty trees were cultivated in the field. The distance between plant to plant and row to row was 20x20 feet. Experiment was based on the following genotypes and varieties

\section{Genotypes}

G-04, G-09, G-10, G-12, G-13, G-15, G-16, G-17, G-19, G-20, G-26, G-29, G-33

\section{Varieties}

Paynee and Serr.

\section{Result and Discussion}

The research work on screening and evaluation of exotic and indigenous walnut germplasm was conducted at Agriculture research institute Mingora swat during 2015. Data recorded the following parameter are presented in Table 1-10, while the original replicated data is placed in Table $1 \mathrm{a}-10 \mathrm{a}$. The result are briefly describe as under. 


\section{Picking date}

Frequency distribution analysis of picking dates is presented in Table 1 while the original data is presented in Table $1 \mathrm{a}$.

Table 1: Frequency distribution analysis of thirteen walnut geno types and varieties based on picking date.

\begin{tabular}{|c|c|c|}
\hline Picking date & Frequency & Percentage \\
\hline Early picking $\left(01^{\text {th }}-09^{\text {th }}\right.$ September $)$ & 4 & $26.66 \%$ \\
\hline Mid picking $\left(10^{\text {th }}-18^{\text {th }}\right.$ September $)$ & 3 & $20 \%$ \\
\hline Late picking $\left(19^{\text {th }}-27^{\text {th }}\right.$ September $)$ & 8 & $53.33 \%$ \\
\hline
\end{tabular}

Table 1a: Original data for picking dates of different genotypes and varieties.

\begin{tabular}{|c|c|}
\hline Genotype/Variety & Picking Date \\
\hline PAYNEE & 25-sep-2015 \\
\hline SERR & 20-sep-2015 \\
\hline G-04 & 21-sep-2015 \\
\hline G-09 & 21-sep-2015 \\
\hline G-10 & 03-sep-2015 \\
\hline G-12 & 24-sep-2015 \\
\hline G-13 & 07-sep-2015 \\
\hline G-15 & 21 -sep-2015 \\
\hline G-16 & 21-sep-2015 \\
\hline G-17 & 15-sep-2015 \\
\hline G-19 & 22-sep-2015 \\
\hline G-20 & 14-sep-2015 \\
\hline G-26 & 07 -sep-2015 \\
\hline G-29 & 17-sep-2015 \\
\hline G-33 & 01 sep-2015 \\
\hline
\end{tabular}

Data for genotype and varieties showed that out of thirteen walnut genotypes and two varieties $26.66 \%$ (G-10, G-13, G-26, G-33) were the early picking ( $1^{\text {st }}-9^{\text {th }}$ Sept) followed by $20 \%$ (G$17, \mathrm{G}-20, \mathrm{G}-29)$ as the mid picking $\left(10^{\text {th }}-18^{\text {th }} \mathrm{Sept}\right)$ while 53.33 \% (Paynee, Serr, G-04, G-09, G-12, G-15, G16, G19), where the late picking $\left(19^{\text {th }}-27^{\text {th }}\right.$ Sept $)$ genotype and varieties. (G-33) was the early picking $\left(01^{\text {th }}-09^{\text {th }}\right.$ Sept $)$ genotype while paynee the late picking $\left(27^{\text {th }}\right.$ Sept) genotype and variety.

\section{With husk weight $(g)$}

Frequency distribution of nut with husk weight is presented in Table 2 while the original data is present in Table $2 \mathrm{a}$.

Table 2: Frequency distribution analysis of thirteen walnut genotypes and two varieties for nut with husk weight $(\mathrm{g})$.

\begin{tabular}{|c|c|c|}
\hline Nut With Husk Weight (G) & Frequency & Percentage \\
\hline$(22.9-41.9)$ & 5 & $33.33 \%$ \\
\hline$(42.0-61.0)$ & 6 & $40 \%$ \\
\hline$(61.1-80.0)$ & 4 & $26.66 \%$ \\
\hline
\end{tabular}

Table 2a: Original data for nut with husk weight $(\mathrm{g})$ of different genotypes and varieties.

\begin{tabular}{|c|c|}
\hline Genotype/variety & Nuts with husk weight(g) \\
\hline PAYNEE & 38.3 \\
\hline SERR & 22.9 \\
\hline G-04 & 29.0 \\
\hline G-09 & 58.2 \\
\hline G-10 & 52.0 \\
\hline G-12 & 56.6 \\
\hline G-13 & 29.5 \\
\hline G-15 & 80.0 \\
\hline G-16 & 60.5 \\
\hline G-17 & 68.0 \\
\hline G-19 & 34.2 \\
\hline $\mathrm{G}-20$ & 80.0 \\
\hline G-26 & 66.0 \\
\hline G-29 & 59.0 \\
\hline G-33 & 53.0 \\
\hline
\end{tabular}

Data showed that out of thirteen walnut genotypes and two varieties 33.33\% (Paynee, Serr, G-04, G-13,G-19) ranged between $22.9-41.9(\mathrm{~g})$ nut with husk weight, followed by $40 \%$ (G-09,G-10,G-12,G-16,G-29,G-33) ranged between 42-61(g), while $26.66 \%$ (G-15, G-17, G-20, G-26) ranged between 61.180.0 (g) Maximum nut with husk weight was shown by G-20 and G-15 (80.0g), while the minimum was noted in Serr (22.9g).

\section{Nut fresh weight (g)}

Table 3: Frequency distribution analysis of thirteen walnut genotypes and two varieties for nut fresh weight $(\mathrm{g})$.

\begin{tabular}{|c|c|c|}
\hline Nut Fresh Weight (G) & Frequency & Percentage \\
\hline$(11.5-17.3)$ & 4 & $26.66 \%$ \\
\hline$(17.4-23.2)$ & 8 & $53.33 \%$ \\
\hline$(23.3-29.1)$ & 3 & $20.00 \%$ \\
\hline
\end{tabular}

Frequency distribution analysis of nut fresh weight is presented in Table 3 while the original data is presented in Table 3a. Data of nut fresh weight showed that out of total thirteen walnut genotypes and two varieties $26.66 \%$ (Paynee, Serr, G-04, G-13) ranged between $11.5-17.3$ (g) followed by $53.33 \%$ (G-9, G-10, G-12, G-16, G-17, G-19, G-29, G-33) ranged between 17.4-23.2(g) while 20\% (G-15,G-20,G-26) ranged between 23.329.1(g). Maximum nut fresh weight was showed by G-15 (29g), while the minimum was noted in G-13(11.5g). 
Table 3a: Original data for nut fresh weight $(\mathrm{g})$ of different genotypes and varieties.

\begin{tabular}{|c|c|}
\hline Genotype/Variety & Nut Fresh Weight(G) \\
\hline PAYNEE & 16 \\
\hline SERR & 17 \\
\hline G-04 & 13.5 \\
\hline G-09 & 22.3 \\
\hline G-10 & 20.5 \\
\hline G-12 & 20.6 \\
\hline G-13 & 11.5 \\
\hline G-15 & 29 \\
\hline G-16 & 20.5 \\
\hline G-17 & 22 \\
\hline G-19 & 18.7 \\
\hline G-20 & 23.5 \\
\hline G-26 & 26 \\
\hline G-29 & 23 \\
\hline G-33 & 20.5 \\
\hline
\end{tabular}

\section{Dried nut weight $(g)$}

Frequency distribution analysis of dried nut weight is presented in Table 4 while the original data is presented in Table 4a.

Table 4: Frequency distribution analysis of thirteen walnut genotypes and two varieties for dried nut weight (g).

\begin{tabular}{|c|c|c|}
\hline Dried Nut Weight (G) & Frequency & Percentage \\
\hline$(8.1-12.43)$ & 5 & $33.33 \%$ \\
\hline$(12.5-16.83)$ & 9 & $60 \%$ \\
\hline$(16.9-21.23)$ & 1 & $6.66 \%$ \\
\hline
\end{tabular}

Table 4a: Original data for dried nut weight $(\mathrm{g})$ of different genotypes and varieties.

\begin{tabular}{|c|c|}
\hline Genotype/Variety & Dried Nut Weight(G) \\
\hline PAYNEE & 10 \\
\hline SERR & 12.8 \\
\hline G-04 & 10.1 \\
\hline G-09 & 14.2 \\
\hline G-10 & 11.3 \\
\hline G-12 & 15.2 \\
\hline G-13 & 8.1 \\
\hline G-15 & 21.1 \\
\hline G-16 & 13.4 \\
\hline G-17 & 14 \\
\hline G-19 & 11.7 \\
\hline G-20 & 14.5 \\
\hline G-26 & 16.8 \\
\hline G-29 & 13.3 \\
\hline G-33 & 15.2 \\
\hline
\end{tabular}

Data pertaining dried nut weight of Genotypes and varieties showed that out of thirteen genotypes and two varieties of walnut $33.33 \%$ (Paynee, G-04,G-10,G-13, G-19) range between 8.1-12.43 (g) 60\% followed by (Serr, G-09, G-12, G-16, G-17, G-20, G-26, G-29 G-33) range between12.5-16.83 (g) while 6.66\%(G-15) ranged between 16.9-21.23(g). Maximum dried nut weight was shown by G-15 (21.1g), while the minimum was noted in G-13 (8.1g).

\section{Kernel percentage}

Frequency distribution analysis regarding Kernel percentage of kernel presented in Table 5 while the original data is presented in Table $5 \mathrm{a}$.

Table 5: Frequency distribution analysis of thirteen walnut genotypes and two varieties for kernel percentage.

\begin{tabular}{|c|c|c|}
\hline Kernel percentage & Frequency & Percentage \\
\hline$(38-43.6)$ & 3 & $20 \%$ \\
\hline$(43.7-49.3)$ & 5 & $33.33 \%$ \\
\hline$(49.4-55)$ & 7 & $46.66 \%$ \\
\hline
\end{tabular}

Table 5a: Original data for kernel percentage of different genotypes and varieties.

\begin{tabular}{|c|c|}
\hline Genotype/Variety & Kernel Percentage \\
\hline PAYNEE & 54 \\
\hline SERR & 50 \\
\hline G-04 & 48 \\
\hline G-09 & 51 \\
\hline G-10 & 54 \\
\hline G-12 & 51 \\
\hline G-13 & 43 \\
\hline G-15 & 38 \\
\hline G-16 & 55 \\
\hline G-17 & 47 \\
\hline G-19 & 46 \\
\hline G-20 & 46 \\
\hline G-26 & 49 \\
\hline G-29 & 53 \\
\hline G-33 & 43 \\
\hline
\end{tabular}

Data regarding kernel percentage of the genotypes and varieties revealed that out of total thirteen genotypes and two varieties of walnut $20 \%$ (G-13, G-15, G-33) had a kernel percentage in the range of 38-43.6, 33.33\% ( G-04, G-17, G-19, G-20, G-26) were noted with a kernel percentage of 43.7-49.3 while 33.33\% (Paynee, Serr, G-09, G-10, G-12, G-16, G-29) ranged between 49.4-55. Maximum kernel percentage was shown by G-16 (55) and Paynee, while minimum was noted in G-15 (38\%).

\section{Nut size: $(\mathrm{m})$}

The nut size frequency distribution analysis is presented in Table 6 while the original data is presented in Table 6 a. 
Table 6: Frequency distribution analysis of thirteen walnut genotypes and two varieties for nut size $\left(\mathrm{mm}^{2}\right)$.

\begin{tabular}{|c|c|c|}
\hline Nut Size $\left(\mathbf{m m}^{2}\right)$ & Frequency & Percentage \\
\hline$(937.9-1238.7)$ & 4 & $26.6 \%$ \\
\hline$(1239-1539.8)$ & 5 & $33.3 \%$ \\
\hline$(1540-1840.8)$ & 6 & $40 \%$ \\
\hline
\end{tabular}

Table 6a: Original data for nut size of different genotypes and varieties.

\begin{tabular}{|c|c|}
\hline Genotype/variety & Nut size $\left(\mathbf{m m}^{\mathbf{}} \mathbf{)}\right.$ \\
\hline PAYNEE & 1109.8 \\
\hline SERR & 1326.2 \\
\hline G-04 & 961.3 \\
\hline G-09 & 1459.6 \\
\hline G-10 & 1692 \\
\hline G-12 & 1840.4 \\
\hline G-13 & 937.9 \\
\hline G-15 & 1480.9 \\
\hline G-16 & 1505.6 \\
\hline G-17 & 1663.6 \\
\hline G-19 & 1237.0 \\
\hline G-20 & 1668.7 \\
\hline G-26 & 1797.0 \\
\hline G-29 & 1631.0 \\
\hline G-33 & 1316.5 \\
\hline & \\
\hline & \\
\hline
\end{tabular}

Data regarding nut size of revealed that out of total thirteen genotypes and two varieties of walnut (26.6\%), (Paynee, G-04, G-13, G-19) ranged between $937.9-1238.7 \mathrm{~mm}^{2}$ followed by 33.33\% (Serr, G-9, G-15, G-16, G-33) ranged between 1239$1539.8 \mathrm{~mm}^{2}$ while $40 \%$ (G-10, G-12, G-17, G-20, G-26 and G-29) had a nut size of $1540-1840.8 \mathrm{~mm}^{2}$. The maximum nut size was recorded in G-12 (1840.4 $\left.\mathrm{mm}^{2}\right)$ while the minimum nut size was noted in G-13 (937.9 $\left.\mathrm{mm}^{2}\right)$.

\section{Kernel color}

Frequency distribution analysis of kernel color is presented in Table 7, while the original data is presented in Table 7a.

Table 7: Frequency distribution analysis of thirteen walnut genotypes and two varieties for kernel color.

\begin{tabular}{|c|c|c|}
\hline Kernel Color & Frequency & Percentage \\
\hline Light & 3 & $20 \%$ \\
\hline Extra light & 1 & $6.6 \%$ \\
\hline Amber & 1 & $6.6 \%$ \\
\hline Light Amber & 9 & $60 \%$ \\
\hline Dark Amber & 1 & $60 \%$ \\
\hline
\end{tabular}

Table 7a: Original data for Kernel color of different genotypes and varieties.

\begin{tabular}{|c|c|}
\hline Genotype/Variety & Kernel Color \\
\hline PAYNEE & Light \\
\hline SERR & Extra light \\
\hline G-04 & Light amber \\
\hline G-09 & Light amber \\
\hline G-10 & Dark amber \\
\hline G-12 & Light amber \\
\hline G-13 & Light amber \\
\hline G-15 & Light \\
\hline G-16 & Light \\
\hline G-17 & Amber \\
\hline G-19 & Light amber \\
\hline G-20 & Light amber \\
\hline G-26 & Light amber \\
\hline G-29 & Light amber \\
\hline G-33 & Light amber \\
\hline
\end{tabular}

Data showed that out of total thirteen walnut genotype and two varieties $20 \%$. (Paynee, G-15, G-16) had light color, followed by $6.6 \%$ (Serr) as extra light color while 6.6\% (G-17) showed amber color. $60 \%$ (G-4, G-9, G-12, G-13, G-19, G-20, G-26, G-29 and $\mathrm{G}-33$ ) were light amber and $6.6 \%(\mathrm{G}-10)$ was recorded as dark amber kernel color.

\section{Kernel taste}

Kernel taste frequency distribution analysis is presented in Table 8, while the original data is presented in Table-8a.

Table 8: Frequency distribution analysis of thirteen walnut genotypes and two varieties for kernel taste.

\begin{tabular}{|c|c|c|}
\hline Kernel Taste & Frequency & Percentage \\
\hline Very Good & 2 & $13.3 \%$ \\
\hline Good & 10 & $66.6 \%$ \\
\hline Fair & 3 & $20 \%$ \\
\hline
\end{tabular}

Table 8a: Original data for kernel taste of different genotypes and varieties.

\begin{tabular}{|c|c|}
\hline Genotypes/Varieties & Kernel Taste \\
\hline PAYNEE & Good \\
\hline SERR & Good \\
\hline G-04 & Fair \\
\hline G-09 & Fair \\
\hline G-10 & Good \\
\hline G-12 & Good \\
\hline G-13 & Good \\
\hline G-15 & Good \\
\hline G-16 & Good \\
\hline G-17 & Fair \\
\hline
\end{tabular}




\begin{tabular}{|c|c|}
\hline G-19 & Very Good \\
\hline G-20 & Very Good \\
\hline G-26 & Good \\
\hline G-29 & Good \\
\hline G-33 & Good \\
\hline
\end{tabular}

Data shows that out of thirteen genotypes and two varieties of walnut $13.3 \%$ (G-19, G-20) showed very good kernel taste followed by 66.6\% (Paynee, Serr, G-10, G-12, G-13, G-15, G-16, G-26, G-29, G-33) as good kernel taste was observed, while in 20 $\%$ (G-09, G-04, and G-17) showed fair kernel taste.

\section{Yield per plant $(\mathrm{kg})$}

Frequency distribution analysis of yield potential per plant is presented in Table 9, while the original data is presented in Table 9a.

Table 9: Frequency distribution analysis of thirteen walnut genotypes and two varieties for yield per plant $(\mathrm{kg})$.

\begin{tabular}{|c|c|c|}
\hline Yield Per Plant (Kg) & Frequency & Percentage \\
\hline$(10.250-12)$ & 10 & $66.6 \%$ \\
\hline$(12.1-13.85)$ & 2 & $13.33 \%$ \\
\hline$(14-15.75)$ & 3 & $20 \%$ \\
\hline
\end{tabular}

Table 9a: Original data for Yield per plant $(\mathrm{kg})$ of different genotypes and varieties.

\begin{tabular}{|c|c|}
\hline Genotypes/varieties & Yield per plant (kg) \\
\hline PAYNEE & 15 \\
\hline SERR & 10.360 \\
\hline G-04 & 15.500 \\
\hline G-09 & 13.5 \\
\hline G-10 & 15.200 \\
\hline G-12 & 10.250 \\
\hline G-13 & 12.5 \\
\hline G-15 & 10.600 \\
\hline G-16 & 10.400 \\
\hline G-17 & 12.250 \\
\hline G-19 & 10.300 \\
\hline G-20 & 11 \\
\hline G-26 & 11 \\
\hline G-29 & 11.700 \\
\hline G-33 & 11 \\
\hline
\end{tabular}

Data regarding yield potential per plant revealed that out of thirteen genotypes and two varieties of walnuts $66.6 \%$ (Serr, G-12, G-15, G-16, G-17, G-19, G20, G-26, G-29, G-33) gives $10.250-12 \mathrm{~kg}$ yield per plant, followed by $13.33 \%$ (G-09, G-12) as having yield, ranged between $12.1-13.85 \mathrm{~kg}$ per plant, while $20 \%$ (Paynee, G-04, G10) produces $14-15.75 \mathrm{~kg}$ yield per plant. Maximum yield 15.200 was recorded the minimum is 10.250 was recorded in G-12.

\section{Number of nuts per $\mathrm{kg}$}

Number of nuts per kg frequency distribution analysis is presented in Table 10, while the original data is presented in Table 10a.

Table 10: Frequency distribution analysis of thirteen walnut genotypes and two varieties for number of nuts per $(\mathrm{kg})$.

\begin{tabular}{|c|c|c|}
\hline Number of nuts per (kg) & Frequency & Percentage \\
\hline$(50-74.33)$ & 8 & $53.3 \%$ \\
\hline$(75-99.33)$ & 4 & $26.6 \%$ \\
\hline$(100-124.33)$ & 3 & $20 \%$ \\
\hline
\end{tabular}

Table 10a: Original data for number of nuts per $\mathrm{kg}$ of different genotypes and varieties.

\begin{tabular}{|c|c|}
\hline Genotypes/varieties & Number of nuts per kg \\
\hline PAYNEE & 105 \\
\hline SERR & 101 \\
\hline G-04 & 93 \\
\hline G-09 & 76 \\
\hline G-10 & 89 \\
\hline G-12 & 73 \\
\hline G-13 & 123 \\
\hline G-15 & 50 \\
\hline G-16 & 72 \\
\hline G-17 & 66 \\
\hline G-19 & 83 \\
\hline G-20 & 53 \\
\hline G-26 & 63 \\
\hline G-29 & 70 \\
\hline G-33 & 66 \\
\hline
\end{tabular}

Data for number of nuts per $\mathrm{kg}$ revealed that in thirteen genotypes and two varieties of walnut 53.3\% (G-12, G-15, G-16, G-17, G-20, G-26, G-29, G-33) ranged between 50 -74.33 nuts per kg followed by $26.6 \%$ (G-04, G-09, G-10, G19) having 75-99.33 nuts per $\mathrm{kg}$, while $20 \%$ (Paynee, Serr, G-13) had $100-124.33$ nuts per $\mathrm{kg}$. The maximum nuts per kg was recorded in G-13 is 123 while the minimum nuts per $\mathrm{kg}$ was recorded in G-15 is 50 .

\section{Conclusion and Recommendations}

Based on the above observation following conclusion are made. For G-04 gave maximum yield per tree, G-15 nut with husk weight, nut fresh weight and dried nut weight while G-16 have high kernel percentage, number of nuts per kg was recorded in G-13. In case of varieties maximum yield per tree, kernel percentage and number of nuts per kg was recorded in Paynee, while maximum nut size, nut with husk weight, nut fresh weight and dried nut weigh was noted in variety Serr. Based on the above conclusion, the following recommendations are made. 
For maximum yield per tree G-04, number of nuts per kg G-13 and maximum nuts size G-12 is recommended. For better yield, maximum number of nuts per kg Paynee variety is recommended, whereas for maximum nut size variety Serr is recommended.

\section{References}

1. Akca Y, Mehmet S (1997) The relationship between dichogamy and yield nut characteristics in Juglans regia L. Acta Hort 442: 215-216.

2. Akca, Y, Ozongun $S$ (2004) Selection of late leafing, late flowering laterally fruitful walnut (Juglans regia $L$.) types in Turkey. New Zealand J Crop Hort Sci 32(4): 337-342.

3. Aslantas R (2006) Identification of superior walnut (Juglans regia L.) genotypes in north-eastern Anatolia, Turkey. New Zealand J Crop Hort Sci 34(3): 231-237.

4. Manning WE (1978) The classification within the Juglandaceae. Ann Missouri Bot Gard 65(4): 1058-1087.

5. Fjellstrom RG, Parfitt DE (1995) Phylogenetic analysis and evolution of the Genus Juglans (Juglandaceae) as determined from nuclear genome restriction fragment length polymorphism (RFLPs). Plant Syst Evol 197(1): 19-32.

6. Fernandez-Lopez J, Aleta N, Alia R (2000) Forest genetic resources conservation of Juglans regia L. IPGRI, Rome, Italy 20-25.

7. Ducci F, Rogatis A, Proietti R (1997) Protezionedellerisorse genetiche di Juglans regia L. Ann Inst Sper Selv 26: 35-55.

8. MINFAL (2000) Agriculture Statistics of NWFP 1999-2000. Ministry for Food, Agriculture and Livestock, Economic Wing, Islamabad, Pakistan.

9. Ali M, Hullah A, Khan F (2010) Fruit properties and nutritional composition of some walnut cultivars grown in Pakistan. Pak J Nuts 9 (3): 15240-15244.

10. Piccirillo P, Petriccione M (2005) Walnut collection of the Italian research council of agriculture in Caserta. Acta Hort 705: 177 181.

11. Davis L, Stonehouse W, Loots DT, Petersen JM, Van FH, et al. (2006) The effects of high walnut and cashew nut diets on the antioxidant status of subjects with metabolic syndrome. Eur J Nutr 46(3): 155-164.

12. Cannella C, Dernini S (2005) Walnut insights and nutritional value. Acta Hort 705: 547-550.

13. Pua C, Davey MR (2007) Biotechnology in agriculture and forestry. Walnuts 60: 349-370.

14. Kerr G (1993) Establishment and provenance of walnut in Britain. Forestry 66(4): 381-393.
15. Voulgaridis V, Vassiliou VG (2005) The walnut wood and its utilization to high Value products. Acta Hort 705: 69-81.

16. Zubair AZ, Din UD, Ullah S, Khan SA, Shah HU (2011) Fatty acid Profile and aflatoxin contamination of walnut ( Juglans regia L.) J Agric and Bio Sci 6(9): 1-8.

17. Khattak MS, Ali S, Wahab, Shah M (2000) Genetic biodiversity in the segregating population of walnut (Juglans regia L.) at Kurram Agency, Parachinar. Pakistan J Bio Sci 3(6): 965-966.

18. Rahman K, Ali N, khan A, Bakht J, Ali R (2009) Responses of various indigenous walnut genotypes to graft take success. Sarhad. J Agric 25(3): 399-403.

19. Kuden A, Kaska N, Turemis N (1997) Walnut selection in middle Taurus Mountains. Acta Hort 442: 117-120.

20. Kazankaya A, Koyuncu M, Koyuncu F, Yarilgac T, Sen SM (2001) Some nut properties of walnuts (Juglans regia L.) of Edremit country. Acta Hort 544(544): 97-100.

21. Khattak SM, Khattak SG, Rafiq M (2007) Evaluation of low chilling walnuts. Sarhad J 23(1): 65-68.

22. Iannamico L, CalvoP, Castro HR (2006) The behavior of ten late sprouting Walnut cultivars in the Alto valley of Rio Negro, Ptagonia (Argentina). Acta Hort 705: 493-497.

23. Lansari A, ElHassani A, Nabil D, Germain E (2001) Preliminary results on walnut germplasm evaluation in Morocco. Acta Hort 544: 27-35.

24. Poirier M, Bodet C, Ploquin S, Saint-Joanis B, Lacointe A, et al. (2005) Walnut cultivar performance of cold resistance in South Central France. Acta Hort 705: 281-285.

25. Sharma SD, Sharma OC, Gautam DR (2005) Studies on the variability in nut characters of seedling trees growing in different locations of Himachal Pradesh, India. Acta Hort 705: 167-171.

26. Sharma SH, Sharma OC (2001) Studies on variation in nut and kernel characters and selection of superior walnut seedlings (Juglans regia L.) from Garsa and Jogindernagar areas of Himachal Pradesh. Acta Hort 544: 47-50.

27. Sutyemez M (2001) Homogamy types of walnuts selected from Kahramanmaras, Turkey. Acta Hort 544: 89-92.

28. Thompson MM (1993) Exploration and exploitation of new fruit and nut germplasm. In: Janickamd J, Simon JE (Eds.), New crops. Wiley, New York, USA, pp. 155-160.

29. Yarilgac T, Koyuncu F, Koyuncu MA, Kazankaya A, Sen SM (2001) Some Promising walnut selections (Juglans regia L.). Acta Hort 544: 93-96.

30. Zeneli G, Kola H, Dida M (2005) Phenotypic variation in native walnut populations of Northern Albania. Sci Hort 105: 91-100.
Your next submission with Juniper Publishers will reach you the below assets

- Quality Editorial service

- Swift Peer Review

- Reprints availability

- E-prints Service

- Manuscript Podcast for convenient understanding

- Global attainment for your research

- Manuscript accessibility in different formats

( Pdf, E-pub, Full Text, Audio)

- Unceasing customer service

Track the below URL for one-step submission

https://juniperpublishers.com/online-submission.php 